\title{
Total Allowable Catch of Indonesian Southern Bluefin Tuna Thunnus maccoyii and Its Potential Resources in The Indian Ocean
}

\author{
Fathur Rochman*, Maya Agustina, and Gussasta Levi Arnenda \\ Research Institute for Tuna Fisheries, Mertasari st 140, Br. Suwung Kangin, Sidakarya, South \\ Denpasar, Denpasar, Bali, Indonesia 80224.
}

\begin{abstract}
Southern Bluefin Tuna (SBT) is a high value species fished by many countries including Indonesia, and its fishing activities has been regulated by CCSBT. This study aimed to determine the potential resource of Indonesian SBT, utilization, and review of the Total Allowable Catch (TAC) of Indonesian SBT. This research was conducted from January 2017 to April 2018. The primary data used in this study were the otolith samples and the enumeration data of SBT landed in Benoa port from 2012-2017. Virtual Population Analysis (VPA) used in this research was based on a direct aging method using otolith. This research showed that the catch at age structure was distributed from 5-22 years with mean and mode of age were 9.63 and 9 years. The average of the exploitation rate measured was 0.191 per year meaning that the level of exploitation was categorized as underfished. The optimal assumption of the exploitation rate estimated in the range of 1,577 to 2,630 tons per year which is higher than the TAC provided by CCSBT. It was concluded that from 2015 onwards, the catch efforts were more effective and efficient with the increasing level of the exploitation and the decreasing number of efforts.
\end{abstract}

\section{Introduction}

Southern Bluefin Tuna (Thunnus maccoyii) (SBT: Southern Bluefin Tuna) is one of the tuna that has a higher economic value than the other tuna species. The catch of SBT $90 \%$ is to meet the need of the Japanese export market [19]. Southern Bluefin Tuna in the Indian Ocean evenly distributed from the east coast of Argentina to the east coast of New Zealand at the coordinate $30-50^{\circ} \mathrm{S}$ dan $70-190^{\circ} \mathrm{E}$ [2]. Southern Bluefin Tuna is a highly migratory species where a part of its life cycle, especially in reproductive cycle, is carried out in Indonesia water specifically in southeastern islands of Java, Bali and Nusa Tenggara to around Indonesian Exclusive Economic Zone (IEEZ) [6, 16, 5]. Reproductive cycle of SBT related to the movement of spawning stock biomass from the water around Tasmania (Australia) to Indonesian water from September to April each year [8].

Spawning stock biomass entering the spawning ground area has a longer size compared to other regions [8] and has a high level of gonad maturity and is ready to reproduce [5]. According to [19], SBT fork length sizes entering the spawning area range from $121 \mathrm{cmFL}$

* Corresponding author: fathursmasabio1@gmail.com 
to $191 \mathrm{cmFL}$ with ages of 5 to 22 years higher than the average length of SBT in nursery ground areas that have an average length of $113.70 \mathrm{cmFL}$ up to $116.50 \mathrm{cmFL}$ [15].

Fishing area of Indonesian SBT was divided into two regions, namely the fishing area in the Indonesian Exclusive Economic Zone (IEEZ) region with coordinates of 8-17 ${ }^{\circ} \mathrm{S}$ and 100 $120^{\circ} \mathrm{E}$ and fishing areas outside the IEEZ with the coordinates of $17-40^{\circ} \mathrm{S}$ and $75-125^{\circ} \mathrm{E}$. The target and products produced from the two fishing areas are different from each other. The target of SBT caught in the IEEZ region is spawning stock biomass with a size of the fork length greater than $120 \mathrm{cmFL}$ while the target of SBT caught in the outside of IEEZ has a fork length sizes of less than $120 \mathrm{cmFL}$ with a frozen product.

Southern Bluefin Tuna Management in the Indian Ocean is managed by the Commission for the Conservation of Southern Bluefin Tuna (CCSBT) under the Food and Agriculture Organization (FAO) United Nation which aims to ensure the conservation and the utilization of SBT optimally through appropriate management (CCSBT, 2018). According to [2], the potential of the total biomass of SBT in The Indian Ocean was 135,171 tons with a Maximum Sustainable Yield (MSY) was 33,036 tons. The catches reported in 2016 were 14,445 tons or $43.72 \%$ of MSY. Spawning Stock Biomass (SSB) accounted for 13\% of total biomass or 17,572 tons in 2017. The Total Allowable Catch (TAC) of CCSBT members from 2018 to 2020 is 17,335 tons where Indonesia as CCSBT members has TAC 1,023 tones or $5.9 \%$ of the total TAC.

The aim of this study is to determine the SBT potential stock in spawning ground area, the overview of Indonesian TAC as CCSBT member, the availability of the fishing fleets and comparing with the stock size in the Indian Ocean. This study is important to recognize the potential stock of SBT in the spawning ground area and to optimize the management of the SBT resources.

\section{Materials and Methods}

\subsection{Data Source and Collection}

This study used two primary data including otolith data and catch monitoring data (enumeration data) of SBT caught in spawning ground area of the Eastern Indian Ocean. The otolith was sagittal otolith data obtained from 462 SBT landed in Benoa port Bali during the fishing season from January to December 2017. Catch monitoring data were obtained from the daily enumeration conducted by Research Institute for Tuna Fisheries (RITF) in Benoa port-Bali from in the periods of 2012 to 2017. The otolith data includes fish morphometry data consisting of fork length ( $\mathrm{cm} \mathrm{FL)} \mathrm{and} \mathrm{gilled} \mathrm{gutted} \mathrm{fish} \mathrm{weight}(\mathrm{kg})$. All of the sagittal otoliths were removed, prepare and read following the techniques described by [3] and by [23]. The enumeration data of the Benoa port was chosen because Benoa port was the biggest fishing port in Indonesia where $85 \%$ of SBT landed [21, 8].

The enumeration data consist of the name, the number of vessels, fish morphometry (length and weight), the grade of fish quality (export, reject and local quality) and the coverage of data sample. The fishing area of SBT landed in Benoa fishing port obtained from spawning ground and nursery ground area south of Java, Bali and Nusa Tenggara around the IEEZ of the Indian Ocean (Figure 1). Southern Bluefin Tuna from spawning ground area inside the IEEZ south of Java, Bali and Nusa Tenggara is a fresh product and intended for the export market but SBT from the outside of IEEZ is frozen product and intended for the local market and canning industry. This study only focuses on fresh SBT from the spawning ground area in which suitable for TAC for the export market. 


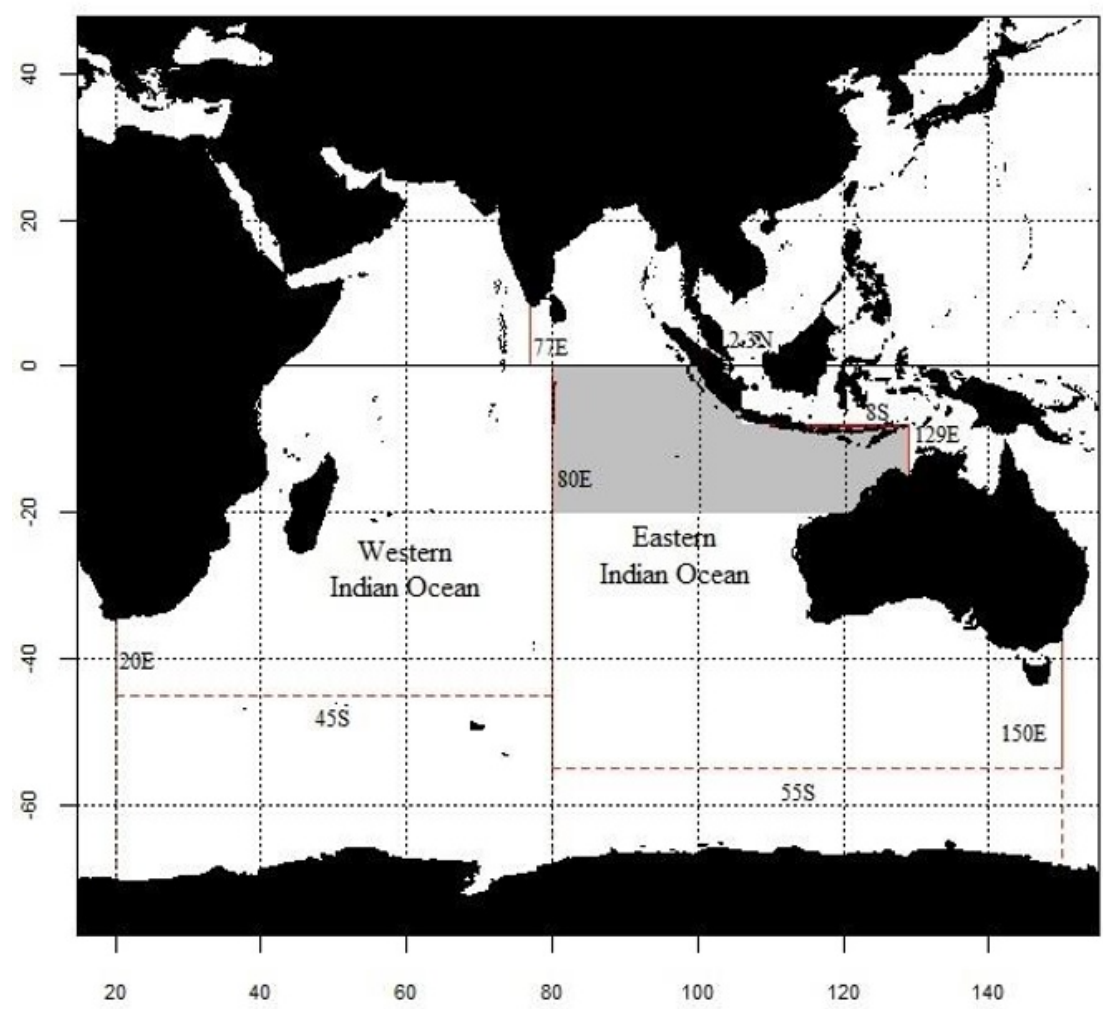

Fig 1. The fishing ground area of Indonesian Southern Bluefin Tuna (Thunnus maccoyii) in the Eastern Indian Ocean (Grey area is the spawning ground area of SBT in the Indian Ocean)

\subsection{Growth and Catch at Age Structure Analysis}

The age sampled of the otolith was developed to determine the age structure, age-length key (ALK) and Von Berthalanffy Growth Function (VBGF) of the Indonesian SBT. Age-length key and VBGF will use to determine the enumeration data in the periods of 2012-2017. The ALK obtained based on the relationship between the growth rate $\left(\frac{\Delta L}{\Delta t}\right)$ and the average of fork length $\bar{L}(t)$ using the equation given by [9]:

$$
\frac{\Delta L}{\Delta t}=a+b \bar{L}(t)
$$

where $a$ is the coefficient of direction, $b$ is the intersection constant on the Y axis, $\Delta L$ is length difference $(\mathrm{cm})$ and $\Delta t$ is age difference (year).

The growth curve of SBT well described using the Von Bertalanffy Growth Model (VBGF) $[11,8]$. The standard of VBGF used in this study was using the equation given by [24]:

$$
L_{t}=L_{\infty}\left(1-e^{-K(t-t 0)}\right)
$$

where $L t$ is the length at the age of $t(\mathrm{~cm}), L_{\infty}$ is the asymptotic length $(\mathrm{cm}), K$ is the growth coefficient, $t$ is the time needed to reach a certain length (year) and $t_{o}$ is theoretical age when 
the length is zero (year). The growth coefficient $(K)$ recognized from the regression coefficient value of ALK [9], where:

$$
\begin{gathered}
K=b \\
L \infty=\frac{-a}{b}
\end{gathered}
$$

The theoretical age when the length is zero $\left(t_{0}\right)$ is determined by [17] with the empirical equation:

$$
\log _{10}\left(-t_{0}\right)=0.3922-0.2752\left(\log _{10} L_{\infty}\right)-1.038\left(\log _{10} K\right)
$$

\subsection{Virtual Population Analysis}

Virtual Population Analysis (VPA) is an analysis of fisheries commercial catch data obtained from fisheries statistics. This method is obtained by combining and analyzing the distribution of the cohort with the age reading of the catch. Virtual Population Analysis is the analysis conducted to obtain the information of the population that should have been in the water to produce the current catch. This method used the assumptions of natural mortality (M) and final fishery mortality based on the historical life of the fish itself. By knowing the natural mortality value, the countdown can be done to get to know how many fish in this cohort that lives year after year and ultimately can be known how much recruitment is there. In the end, it can be known as the coefficient value of fishing mortality $(\mathrm{F})$ of the data.

The natural mortality (M) of SBT is estimated by the calculation of the natural mortality from the maximum age of the fish (otolith reading), for example, the maximum age of SBT is 25 years, it's estimated that the natural mortality is $(1: 25)$ or 0.04 per year. Furthermore, the countdown is carried out from catch data monitoring (2012-2017) with the following formula given by [18]:

$$
N_{(t)}=\left[N_{(t+1)} * \exp ^{(M / 2)}+C_{(t)}\right] * \exp ^{(M / 2)}
$$

where $N_{(t)}$ is the number of fish in the year (t), $t$ is the age of fish, $M$ is the natural mortality and $C_{(t)}$ is the number of catch in the year $(\mathrm{t})$. The estimation of fishing mortality $(\mathrm{F})$ can be known by the formula given by [18]:

$$
F_{(t)}=\ln \frac{N(t)}{N(t+1)}-M
$$

The total mortality $(\mathrm{Z})$ was determined by adding natural mortality $(\mathrm{M})$ and fishing mortality $(\mathrm{F})$.

\section{Result and Discussion}

\subsection{Result}

\subsubsection{Growth}

There were 452 of 462 pairs of otolith sagittae that can be read in this study where this otolith consist of 189 pairs of male fish, 220 pairs of female fish and 43 pairs were unidentified. The result of otolith aging are presented in Appendix 1 and the tabulation of length, weight, and age-based on sex are shown in Table 1. 
Table 1. The number of otolith samples, range (max, min and mean) of length, weight, and age of fish based on the reading of otolith increment of Southern Bluefin Tuna (Thunnus maccoyii) on January to December 2017.

\begin{tabular}{clrrr}
\hline Sex & & Length $(\mathrm{cmFL})$ & Weight $(\mathrm{kg})$ & Age (year) \\
\hline Male $(\mathrm{n}=189)$ & Minimum & 138.0 & 46.0 & 8.0 \\
& Maximum & 196.0 & 140.0 & 18.0 \\
& Mean & 164.0 & 86.6 & 12.7 \\
Female (n=220) & Minimum & 134.0 & 45.0 & 9.0 \\
& Maximum & 195.0 & 157.0 & 18.0 \\
& Mean & 159.4 & 79.2 & 13.0 \\
Unidentified (n=43) & Minimum & 140.0 & 45.0 & 10.0 \\
& Maximum & 184.0 & 160.0 & 20.0 \\
& Mean & 158.7 & 80.8 & 12.4 \\
\hline
\end{tabular}

The relationship between the growth rate $\left(\frac{\Delta L}{\Delta t}\right)$ and the average of fork length $\bar{L}(\mathrm{t})$ (ALK) in each sex were $Y=-0.2297 F L+44.046\left(R^{2}=0.9471\right)$ for males, $Y=-0.1268 F L+24.88$ $\left(R^{2}=0.9426\right)$ for females and $Y=-0.167 F L+31.815\left(R^{2}=0.9355\right)$ for combined sexes. Moreover, from the ALK we can estimate the Growth Coefficient (K) of VBGF growth equation. The growth coefficient $(\mathrm{K})$ was 0.2297 for males, 0.1268 for females and 0.167 for combined sexes. The asymptotic length $\left(\mathrm{L}_{\infty}\right)$ was $192 \mathrm{cmFL}$ for males, $196 \mathrm{cmFL}$ for females and $191 \mathrm{~cm}$ FL for combined sexes. After all of these parameters were known, $t_{0}$ can be recognized by Pauly equation [17] where $t_{0}$ were -0.439 for males, -0.809 for females and 1.081 for combined sexes. The three of those growth parameters were then substituted into Von Berthalanffy Growth Function as follow: $L_{t}=192\left(1-\mathrm{e}^{-0,2297(t+0,439)}\right)$ for males, $L_{t}=196$ $\left(1-\mathrm{e}^{-0,1268(t+0,809)}\right)$ for female and $\mathrm{L}_{\mathrm{t}}=191\left(1-\mathrm{e}^{-0,167(\mathrm{t}+1,081)}\right)$ for combined sexes (Figure 2).

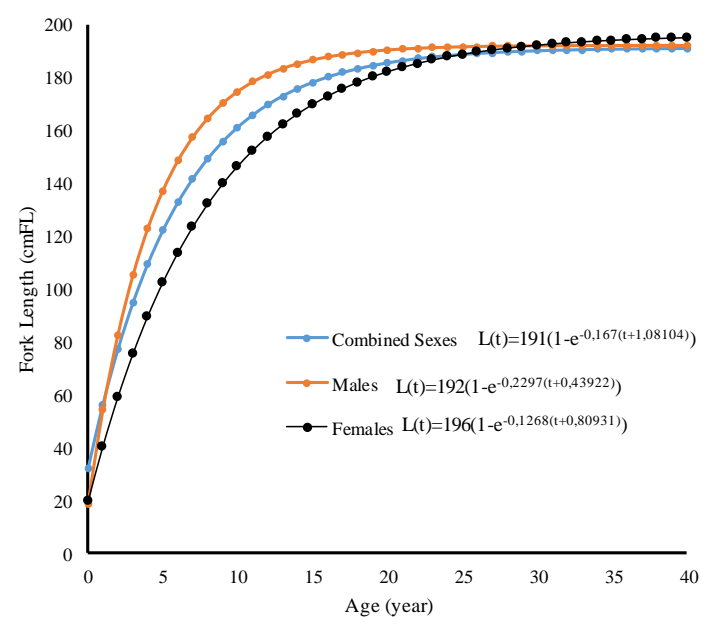

Fig. 2. Von Berthalanffy growth curve of Southern Bluefin Tuna (Thunnus maccoyii) caught by Indonesian longliner based on the otolith age estimation in the periods of January-December 2017

\subsubsection{Catch at Age Structure}

Catch at the age structure of fresh SBT was distributed from the age of 5 years to the age of 22 years with an average of age was 9.63 years and a mode at the age of 9 years. Catch at age structure also showed the normal distribution pattern where mode value was under the age of the first maturity (Figure 3). 


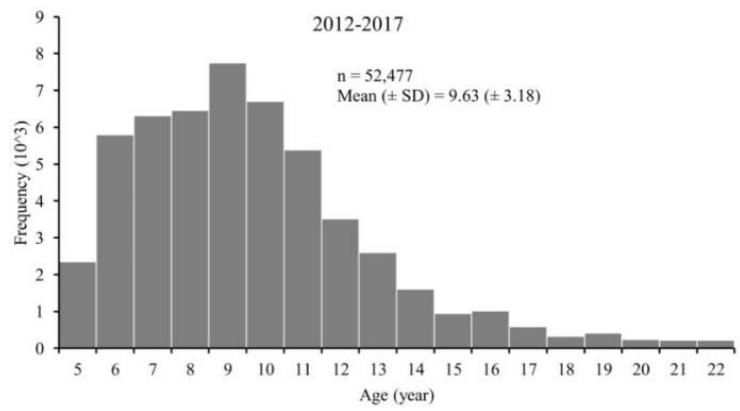

Fig. 3 The total of catch at age structure of fresh Southern Bluefin Tuna (Thunnus maccoyii) caught by Indonesian Longliner in spawning ground area of Indian Ocean in a period of 2012-2017.

The distribution of catch at age structure showed that the mode changed from year to year leading to a younger fish. In 2012, the mode was 10 years but entering 2013-2014 the mode was shifted to 6 years. In 2015-2017, the mode was increased from 7 years (2015) to 8 years (2016) and 9 years (2017) (Figure 4).

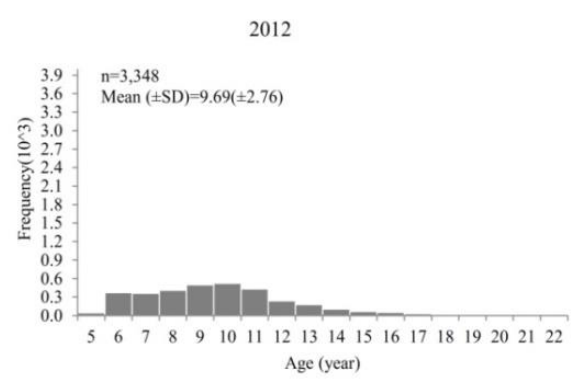

2013

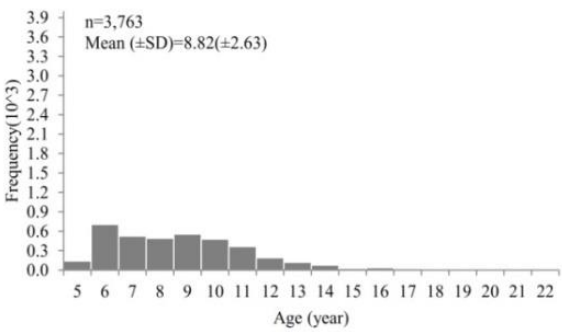

2014

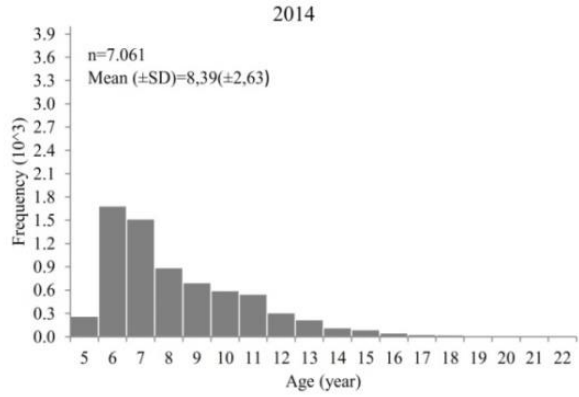

2015

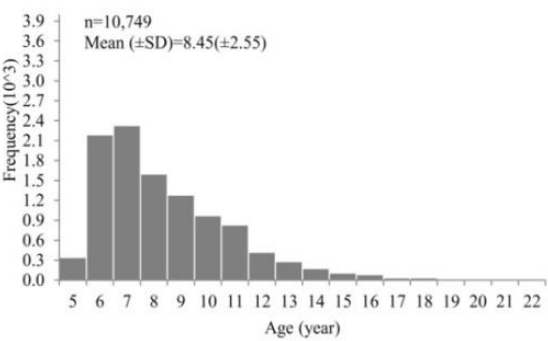

2016

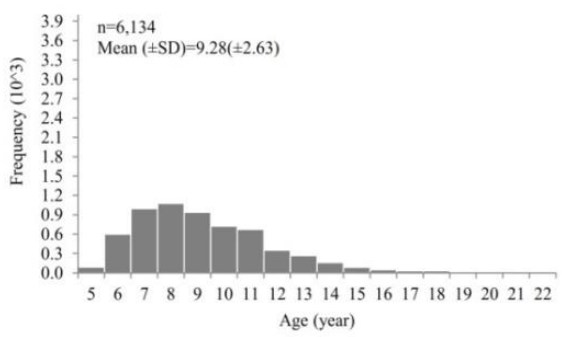

2017

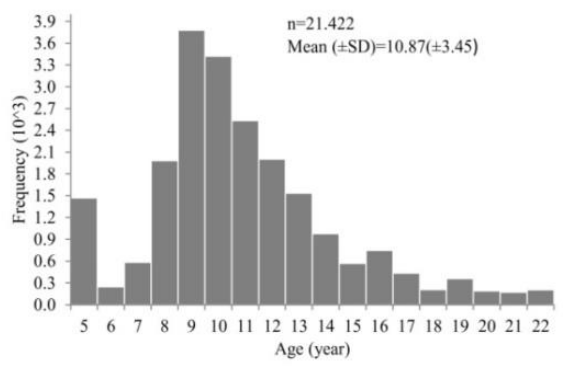

Fig. 4. The annual catch at age structure of fresh Southern Bluefin Tuna (Thunnus maccoyii) caught by Indonesian Longliners in spawning ground area of Indian Ocean in a period of 2012-2017. 


\subsubsection{Virtual Population Analysis}

The virtual population analysis result showed that the catches of fresh SBT in the spawning area from 2012 to 2016 fluctuated from $301,995 \mathrm{~kg}$ to $855,934 \mathrm{~kg}$ with an average of 511,908 $\mathrm{kg}$ per year. Natural mortality estimated from $116,752 \mathrm{~kg}$ to $163,223 \mathrm{~kg}$ with an average of $143,868 \mathrm{~kg}$ per year. Spawning stock biomass estimated from 3,038,247 kg to 3,627,168 kg with an average of $3,197,066 \mathrm{~kg}$ per year. The estimation of the real potential value of spawning stock biomass, catches, and natural mortality depended on the coverage of data enumeration on the landing site. The average value of the coverage data sample is $60 \%$, which means that there is an increase of spawning stock biomass of about $40 \%$ of VPA estimation. The average potential estimation of fresh SBT in spawning ground area was $5,259,682 \mathrm{~kg}$ with the average of catches was $823,599 \mathrm{~kg}$ and natural mortality was $236,686 \mathrm{~kg}$ per year. The average of the exploitation rate was 0.191 meaning that the exploitation was below the allowable threshold $(0.5 \%)$ (Table 2$)$.

Table 2. Virtual Population Analysis estimation and potential estimation of SBT in the spawning area of the Indian Ocean (back-calculation from 2012 to 2016).

\begin{tabular}{|c|c|c|c|c|c|c|c|c|c|}
\hline \multirow{2}{*}{ Year } & \multicolumn{3}{|c|}{ VPA Estimation } & \multicolumn{3}{|c|}{ Potential Estimation } & \multirow{2}{*}{$\begin{array}{c}\sum \text { Vessel } \\
\text { (unit) }\end{array}$} & \multirow{2}{*}{$\begin{array}{c}\text { Cvg. Data } \\
(\%)\end{array}$} & \multirow{2}{*}{$\begin{array}{c}\text { Exp. Rate } \\
\text { (\%) }\end{array}$} \\
\hline & Biomass (kg) & Catches (kg) & Nat. Mort. (kg) & Biomass (kg) & Catches (kg) & Nat. Mort (kg) & & & \\
\hline 2012 & $3,038,247$ & 301,995 & 136,721 & $5,209,614$ & 517,824 & 234,433 & 141 & 58.32 & 0.188 \\
\hline 2013 & $3,393,277$ & 311,027 & 152,697 & $5,928,157$ & 543,373 & 266,767 & 158 & 57.24 & 0.142 \\
\hline 2014 & $3,627,168$ & 557,549 & 163,223 & $5,973,598$ & 918,230 & 268,812 & 190 & 60.72 & 0.183 \\
\hline 2015 & $3,332,152$ & 855,934 & 149,947 & $4,882,990$ & $1,254,300$ & 219,735 & 112 & 68.24 & 0.248 \\
\hline 2016 & $2,594,483$ & 533,036 & 116,752 & $4,304,053$ & 884,267 & 193,682 & 107 & 60.28 & 0.196 \\
\hline AVG & $3,197,066$ & 511,908 & 143,868 & $5,259,682$ & 823,599 & 236,686 & 142 & 60.96 & 0.191 \\
\hline
\end{tabular}

The relationship between the exploitation rate (\%) and the number of operating fleets is presented in Figure 5. From 2012 to 2014, there was a gap between the exploitation rate and the fishing effort but entering 2015 and 2016 the exploitation rate was slightly higher compared with the fishing effort (the number of fleets).

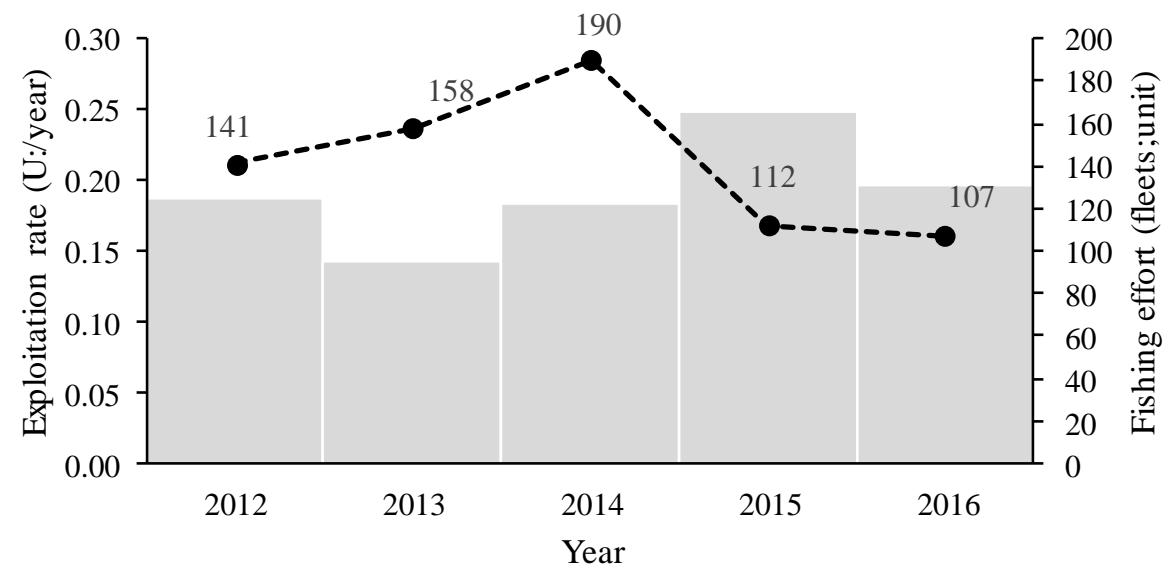

Exploitation rate --๑-- Fishing effort (unit)

Fig. 5. The relationship between the exploitation rate and the number of fishing fleet (effort) of SBT in Indian Ocean 


\subsection{Discussion}

\subsubsection{Growth}

The analysis of the otolith showed that the minimum age was 8 years and the maximum age was 20 years with a minimum length of $134 \mathrm{cmFL}$ and the maximum length of $196 \mathrm{cmFL}$. This result showed that SBT is a species with slow growth and has a high variation in natural size especially fish with age above 10 years. It's supported by [11] and [22] which said that the species of SBT is a long-lived species, has a slow growth coefficient per year and has a high variation in size, especially at the age above 10 years. The ALK produced only for SBT caught in the spawning area with a size of over $138 \mathrm{cmFL}$.

Southern Bluefin Tuna has a slow type of growth, but at the beginning of the year its development can be grown rapidly reaching up $55 \mathrm{~cm}$ FL at the beginning year of its life [11, 8]. The growth coefficient of fresh SBT slightly higher than the SBT in the Central Indian Ocean $[15,11]$. The increasing of the growth coefficient $(\mathrm{K})$ is caused by sexual dimorphism where the coefficient of growth of SBT is higher in spawning areas than that the outside area. This size length suggested as the main factor when the early gonad maturity in male and female fish [7]. Sexual dimorphism also happened in other temperate tuna species Albacore [25]. The sexual dimorphism also occurred in different sex between male and female. The growth coefficient of male fish is higher than that of female fish so that at the same age has a higher length. This also happened in a previous study conducted by $[11,8]$. This difference as a result of a difference in the growth coefficient (K), asymptotic length (Lo) and theoretical age when the length is zero $\left(\mathrm{t}_{0}\right)$ in the Von Bertalanffy growth equation. Male fish has a growth coefficient $(\mathrm{K})$ higher than that female fish but has an asymptotic length lower than female fish so that at an adult age (> 30 years) individual female fish will continue to grow up to more than 40 years old and male individuals will stop growing at \pm 30 years of age (Figure 2). The previous study conducted by [8] with the same object study found that at the age of more than 30 years, male fish will stop growing and female individuals will continue to grow until it approaches the asymptotic length. Von Berthalanffy growth model showed that the SBT caught in the spawning area has a different age structure compared with other fishing areas. This study was found that to achieve the ideal gonadal maturity $>140$ $\mathrm{cmFL}$ as reported by $[4,11,15]$ were obtained at the age of 6 to 7 years.

\subsubsection{Catch at Age Structure}

In the stock assessment, age frequency is an important component that can be used to reconstruct catch at age data structures [24, 12]. Fishing pressure of the specific species recognized by the movement of age mean and age mode of age structure data. This study showed that the fishing pressure conducted in 2012 to 2014 sign by the movement of age mean from 9.96 years to 8.39 years and the age mode from 10 years to 6 years. The decreasing of fishing pressure obtained in 2015-2017 recognized by the increasing of age mean from 8.45 years to 10.87 years and the increasing of age mode from 7 years to 10.87 years. However, the average age of fresh SBT caught by Indonesian longliners in the Indian Ocean is still far below the average value of catches in 2000 of 19.5 years and in 2011 of 16.8 years [8].

\subsubsection{Virtual Population Analysis}

The virtual population analysis showed that the exploitation rate (U) of Indonesian fresh SBT was low with an average of $0.191 \%$ per year. Based on the assumption of the exploitation 
rate, fish stock is determined as overfished or not overfished based on the optimal assumption of the exploitation rate $\mathrm{U}\left(\mathrm{U}_{\mathrm{opt}}\right) \approx 0.5$ [10]. It was in accordance with the study conducted by [1] which uses the MSY reference point as a base of the model. It stated that the stock status of the SBT caught in the Indian Ocean is not overfished or subjected to overfishing. The value of fishing mortality $(\mathrm{F})$ relative to the value of fishing mortality at MSY ( $\left.\mathrm{F}_{\mathrm{MSY}}\right)$ is not more than $0.5 /$ year by compiling the fishing quota for CCSBT member countries. The value of MSY in 2017 was 33,036 tons (30,000-36,000 tons) and the total allowable catch ( TAC) was 14,647 tons in 2017 and 17,647 tons in the period 2018 to 2020 [1].

Population, mortality rate (natural mortality and fishing mortality) and the exploitation rate of SBT can be clearly described in this study. Although the statistical data (enumeration) which was carried out by the RITF (Research Institute for Tuna Fisheries) was not cover the entire capture data of SBT landed at Benoa port, but the VPA size can be adjusted to the existing data coverage. The average enumeration coverage in Benoa-Bali port from the period of 2012 to 2016 was $60 \%$ [13, 14] so that the actual VPA estimation was $40 \%$ higher than the VPA theoretical calculation above. But the value of the mortality rate and the rate of exploitation remain the same even though the fishing data and fish populations that live in the natural area have increased by $40 \%$. with an average estimated potential of 5,259 tons per year, Indonesian tuna longliners must have the potential of $30 \%$ to $50 \%$ of the total potential estimation of SBT in Spawning ground area or equal to 1,577 tons to 2,630 tons per year and higher than that TAC provided by CCSBT as much as 1,023 ton per year.

The balance between efforts (number of fishing fleets) and the level of exploitation can be clearly illustrated in this study. From 2012 to 2014, the number of efforts exceeded the existing level of the exploitation, but in 2015-2016, the number of efforts was below the level of exploitation, making it more efficient in SBT fishing. In order to find out why there was a decrease in the number of fleets from 2015 to 2016, we must conduct a thorough study, not only covering the fish resources aspect but also in the socio-economic aspects related to the tuna longline fleets in Indonesia. Southern Bluefin Tuna is a seasonal commodity and is not the main target of tuna species in the Indian Ocean so a comprehensive study must be conducted to answer the problems in Indonesian longline fisheries overall.

\section{Conclusion}

Catch at age structure of SBT in the spawning area was dominated by young fish with the age of 5 to 22 years and with an average age of 9.63 years. Southern Bluefin Tuna is a longlived fish, slow rate of growth, exhibited sexual dimorphism between males and females and has a difference in growth coefficient between in nursery and spawning ground area. The potential of Indonesian SBT in the spawning area was very high and exceeds the TAC provided by CCSBT. Entering 2015 to 2016, the effort of SBT was more effective and efficient compared with the previous years marked by the increasing level of exploitation rate and the decreasing of the number of efforts (number of fishing fleets). Southern Bluefin tuna is a seasonal commodity and is not the main target species of longline in Indonesia so a comprehensive study (fish resource, socio-economic and environment) is needed to answer these problems.

The authors would like to thank the Ministry of Marine Affairs, Human Resource and Research Agency Marine and Fisheries, and Fisheries Research Centre for all financial support. We also would like to thank and express high appreciation to the enumerators of the Research Institute for Tuna Fisheries (RITF) who have helped to collect data during the research. High appreciation deserves to Mr. Zulkarnaen Fahmi as a director of the Research Institute for Tuna Fisheries (RITF) for valuable input and comments. 


\section{References}

1. CCSBT (Commission for the Conservation of Southern Bluefin Tuna). Report of the twenty-second meeting of the scientific committee. 124 pp (2017).

2. CCSBT (Commission for the Conservation of Southern Bluefin Tuna). Annual catch by flag or gear from 1952 to 2017 inclusive. Retrieved from https://www.ccsbt.org/en/content/sbt-data. (2018)

3. N.P. Clear, J.S. Gunn, and A.J. Rees. Direct validation of annual increment in otolith of juvenile Southern Bluefin Tuna, Thunnus maccoyii by means of a large scale markrecapture experiment with strontium chloride. Fish. Bull. 98: 25-40. (2000) https://spo.nmfs.noaa.gov/sites/default/files/03 2.pdf

4. T.L.O. Davis, and J.H. Farley. Size distribution of Southern Bluefin Tuna (Thunnus maccoyii) by depth on their spawning ground. Fish. Bull. 99: 381-386. (2001). https://www.st.nmfs.noaa.gov/spo/FishBull/992/dav.pdf

5. K. Evans, T.A. Patterson, H. Reid, and S.J. Harley. Reproductive schedules in Southern Bluefin Tuna: Are current assumptions appropriate? PlosONE 7(4):e34550. (2012). doi:10.1371/journal.pone.0034550.

6. J.H. Farley, and T.L.O Davis. The reproductive dynamic of Southern Bluefin Tuna, Thunnus maccoyii, as inferred from direct age data. Fish Bull, 96:223-236. (1998). https://www.researchgate.net/publication/258883653_Reproductive_dynamics_of_sou thern_bluefin_tuna_Thunus_maccoyii

7. J.H. Farley, and T. L. O. Davis. Length and age distribution of SBT in the Indonesian longline catch on the spawning ground. Report CCSBT/ESC/0309/18. 17 pp. (2003).

8. J. H. Farley, J. P. Eveson, T.L.O. Davis, R. Andamari, C.H. Proctor, B. Nugraha, and C.R. Davies. Demographic structure, sex ratio and growth rate of Southern Bluefin Tuna (Thunnus maccoyii) on the spawning ground. PLoS ONE 9(5); e96392. (2014). doi:10.1371/journal.Pone.0096392.

9. J.A. Gulland, \& S.J. Holt.. Estimation of growth parameters for data at unequal time intervals. ICES Journal of Marine Science 25(1): 47-49. (1959) https://doi.org/10.1093/icesjms/25.1.47

10. J.A. Gulland. The Fish Resources of the Oceans: FAO Fishing News (Books) Ltd. Surrey: 255 pp. (1971).

11. J.S. Gunn, J.H. Farley, \& B. Hearn. Catch at age; age at first spawning; historical change in growth; and natural mortality of SBT; An integrated study of key uncertainties in the population biology and dynamic of SBT based on direct age estimates from otolith. FRDC Project no.97/111. Hobart, Australia; CSIRO Marine Research. 97 pp. (2008).

12. M. Herrera, \& L. Pierre. Preparation of data input files for the stock assessment of Indian Ocean Swordfish. IOTC-2011-WPB09-07. 32 pp. (2011).

13. IOTC (Indian Ocean Tuna Commission). Indonesian National Report to the Scientific Committee, 2017. IOTC-2017-SC20-NR09. 24 pp. (2017).

14. IOTC (Indian Ocean Tuna Commission). Indonesian National Report to the Scientific Committee, 2018. IOTC-2018-SC21-NR09. 28 pp. (2018).

15. Y.T. Lin, \& W.N. Tzeng. Sexual dimorphism in the growth rate of Southern Bluefin Tuna Thunnus maccoyii in the Indian Ocean. J. Fish. Soc. Taiwan. 37(2): 135-151. (2010). http://ntur.lib.ntu.edu.tw/retrieve/174675/ 
16. T.P. Patterson, K. Evans, T.I. Carter, \& J.S. Gunn. Movement and behavior of large Southern Bluefin Tuna (Thunnus maccoyii) in the Australian region determined using pop-up satellite archival tags. Fish Oceanog 17: 352-367. (2008). http://www.cmar.csiro.au/biologging4/documents/FOG_finalversion.pdf

17. D. Pauly. Fish Population Dynamic in Tropical Waters: A Manual for Use with Programmable Calculators. ICLARM Studies and Reviews 8. 325 pp. (1984).

18. J.G. Pope. An investigation of the accuracy of virtual population analysis using cohort analysis. Research Bulletin ICNAF. (9): 65-74. (1972). https://www.nafo.int/icnaf/library/res-bull/res-bull-9.pdf\#page $=65$

19. F. Rochman. The utilization of otolith in the study of dynamic population and age structure of Southern Bluefin Tuna, Thunnus maccoyii (Castelnau, 1872) Caught in the Indian Ocean (Postgraduate Thesis). Mathematics and Natural Science, Udayana University, Bali, Indonesia. 103 pp. (2019).

20. F. Rochman, B. Setyadji, \& I. Jatmiko. Impact of the moratorium enforcement on the fishing effort and production of industrial-scale longline tuna fisheries based in Benoa Port-Bali. Indonesian Fisheries Research Journal. 22 (3) 2016:181-188. (2016). http://ejournalbalitbang.kkp.go.id/index.php/jppi/article/view/1545/2735

21. F. Satria, A. Suman, D. Nugroho, B. Nugraha, \& A. Widodo. Indonesian southern Bluefin tuna fisheries, a national report year 2011. Report CCSBT-ESC/1208/SBT Fisheries-Indonesian prepared for the $17^{\text {th }}$ CCSBT Meeting of the Scientific Meeting 27-31 August, Tokyo. Japan. 13 pp. (2012).

22. J.C. Shiao, S.K. Chang, Y.T. Lin, \& W.N. Tzeng. Size and age composition of Southern Bluefin Tuna (Thunnus maccoyii) in the Central Indian Ocean inferred from fisheries and otolith data. Zoological studies. 47(2): 158-171. (2008). http://ntur.lib.ntu.edu.tw/bitstream/246246/174809/1/13.pdf

23. T. Shimose, \& T. Ishihara. A manual for age determination of Pacific Bluefin tuna (Thunnus orientalis). Bull. Fish. Res. Agen. No. 40: 1-11. (2015). https://www.fra.affrc.go.jp/bulletin/bull/bull40/40-01.pdf

24. P. Sparre, \& S.C. Venema. Introduction to Tropical Fish Stock Assesment. Part 1: manual. FAO Fisheries Technical Paper, 306/1 Rev. 2, (FAO Rome): 407 p (1998).

25. A. J. Williams, J. H. Farley, S.D. Hoyle, C.R. Davies, \& S.J. Nicol. Spatial and sexspecific variation in growth of albacore (Thunnus alalunga) across the South Pacific Ocean. PLoS ONE. 7(6): e39318 (2012). doi: 10.1371/journal. pone, 0039318. https://search.proquest.com/docview/1326195495/fulltextPDF/D7C2DEB25A3D414 $\underline{\mathrm{CPQ} / 1 \text { ?accountid }=32506}$ 
Appendix 1. Mean of length (cmFL) and standard deviation of Southern Bluefin Tuna (Thunnus maccoyii) based on the otolith age reading.

\begin{tabular}{rrrr}
\hline $\begin{array}{c}\text { Age Group } \\
\text { (Year) }\end{array}$ & $\begin{array}{c}\text { Otolith Age Reading } \\
\text { The Average of Length (cmFL) }\end{array}$ & SD $( \pm)$ & $\mathrm{n}$ \\
\hline 8 & 138 & 4.24 & 2 \\
9 & 140.75 & 0.96 & 4 \\
10 & 148.30 & 8.29 & 43 \\
11 & 150.75 & 6.77 & 75 \\
12 & 156.89 & 7.27 & 83 \\
13 & 162.62 & 8.99 & 89 \\
14 & 170.41 & 8.57 & 63 \\
15 & 171.36 & 6.36 & 53 \\
16 & 173.90 & 7.37 & 20 \\
17 & 175.50 & 5.39 & 9 \\
18 & 181.37 & 10.25 & 8 \\
19 & 187 & - & 1 \\
20 & 187.50 & 10.6 & 2 \\
\hline Total & & & 452
\end{tabular}

